\title{
Mineralogy and Geochemistry of the Upper Paleocene Shales from Goouydaraq-Goouradaraq, East Azarbaijan, NW Iran
}

\author{
Behzad Hajalilou*, Nasser Ashrafi, Jafar Sharifi \\ Department of Geology, Payame Noor University, Tehran, Iran \\ Email: ^hajalilou@pnu.ac.ir
}

How to cite this paper: Hajalilou, B., Ashrafi, N. and Sharifi, J. (2016) Mineralogy and Geochemistry of the Upper Paleocene Shales from Goouydaraq-Goouradaraq, East Azarbaijan, NW Iran. Open Journal of Geology, 6, 1096-1117. http://dx.doi.org/10.4236/ojg.2016.69082

Received: August 4, 2016

Accepted: September 11, 2016

Published: September 14, 2016

Copyright $\odot 2016$ by authors and Scientific Research Publishing Inc. This work is licensed under the Creative Commons Attribution International License (CC BY 4.0).

http://creativecommons.org/licenses/by/4.0/

\begin{abstract}
In NW Iran, the bluish grey pencil shale intercalated with thin detritic limestone and siltstone was deposited on the grey limestone of Paleocene. Based on the X-ray diffraction results, the shale forming minerals are composed of calcite, quartz, feldspar, dolomite, muscovite, hematite and clay minerals including chlorite, illite, montmorionite, kaolinite and palygorskite. The comparison of major and trace element content of the shale with the typical samples indicates abundance in $\mathrm{CaO}, \mathrm{Sr}$, and $\mathrm{Cs}$ and scarcity in $\mathrm{SiO}_{2}, \mathrm{Al}_{2} \mathrm{O}_{3}$, and $\mathrm{Ba}$. The values of weathering indices imply moderate weathering in the source area and deposition of sediments in an area with relatively high uplift. According to the major and trace elements ratios, provenance of the shale was probably felsic and/or intermediate igneous rock. The elemental ratios and geochemical parameters values such as $\mathrm{Ti} / \mathrm{Zr}=38, \mathrm{Th} / \mathrm{Sc}=0.55, \mathrm{La} / \mathrm{Sc}=1.9, \mathrm{La} / \mathrm{Th}=$ $3.4, \Sigma \mathrm{REE}=117.34, \mathrm{Eu} / \mathrm{Eu}^{*}=0.76$, and $(\mathrm{La} / \mathrm{Yb})_{\mathrm{N}}=8.3$ suggest a immature continental arc setting for the studied shale. The inferred tectonic setting for the studied shale is in agreement with the tectonic evolutionary history of NW Iran during the Upper Cretaceous-Upper Paleocene. The detailed observation of facies distribution in the NW Iran during Cretaceous-Paleocene shows that the studied shale could be supplied from the volcanic-sedimentary succession of Upper-Cretaceous in a basin related to the Neo-Tethys II subduction.
\end{abstract}

\section{Keywords}

Shale, Clay Minerals, Weathering Indices, Continental Arc

\section{Introduction}

The mineralogical and bulk chemical compositions of clastic sedimentary rocks are 
used to determine provenance, evaluate paleoclimates and tectonic activity, and study the evolution of the crust, e.g. [1]-[13]. The study of mudrocks is important for understanding a large portion of the earth's sedimentary rocks, because they are 65 percent of all sedimentary rocks [14]. Mudrocks clay mineralogy has been the mineralogical procedure most often applied to reconstruct provenance. For example, illite is the predominant component of marine shales more so than in nonmarine shales [15]. Due to the fine-grained nature and impermeability, mudrocks retain most of the mineral constituents of the source rocks [16]-[18]. Thus, the bulk geochemistry of mudrocks preserves the near-original signatures of the provenance and more accurately reflects weathering and diagenetic history. The ratios of immobile trace elements, such as $\mathrm{Cr} / \mathrm{Th}$, $\mathrm{Th} / \mathrm{Sc}, \mathrm{Th} / \mathrm{Co}, \mathrm{La} / \mathrm{Sc}$, and La/Co, are reliable indicators of provenance [19]. For example, $\mathrm{Th} / \mathrm{Sc}$ ratio and $\mathrm{Zr} / \mathrm{Sc}$ ratio increase going from mafic to felsic source areas, but passive margin muds show anomalous $\mathrm{Zr}$ related to recycling of older sediments [5].

The present paper describes the mineralogy and major and trace element geochemistry of Upper Paleocene pencil shales from Goouydaraq-Goouradaraq (GG), NW Iran and discusses inferred source rocks, paleoweathering pattern and paleotectonics. The study also compares the major element contents of the GG shales with their counterparts in other regions of the world. This is the first study which presents mineralogical and major and trace element data for the GG shales.

\section{Geology}

During the Upper Cretaceous, there were two different sedimentary basins in the NW Iran including Ahar, Kaleybar, and Heris area: the first is characterized by thick detrital sediments (Ayatakhlet basin) and the second is described by dominantly calcareous sediments associated with expanded volcanic activity (Qaradagh-Sheyvardagh basin) [20]. The best Outcrop of the Ayatakhlet basin sediments is located in the south of Goouradaraq village. The studied area is a part of the Ayatakhlet basin and composed of bluish grey shale intercalated with thin detritic limestone and siltstone.

The study area (near to Goouydaraq and Goouradaraq villages) is situated in the Alborz-Azarbaijan zone (Figure 1) [21] [22], according to the zonation of Iranian crust and placed on the 1/100,000 geological map of Khoja (Figure 2). Contact of the GG shale is to the south Miocene red conglomerate and breccia, to the east Eocene pyroclastic and intermediate volcanic rocks, to the west Paleocene dark grey and bluish grey biomicrosparite limestones, and to the north Plio-Quaternary unconsolidated conglomerate associated with interbedded marl (Figure 3(a)). The GG shales are bluish and green grey in colour and have pencil structure (Figure 3(b)). They belong to Upper Paleocene based on the existing fossils [23]. The GG shales are associated with interbedded thin limestone and siltstone which all are cut by micro-dioritic dykes. There is bioturbation traces on the surface of some siltstone layers (Figure 3(c)).

\section{Materials and Methods}

More than thirty-five samples were collected from the GG shale, siltstone, and limestone. 


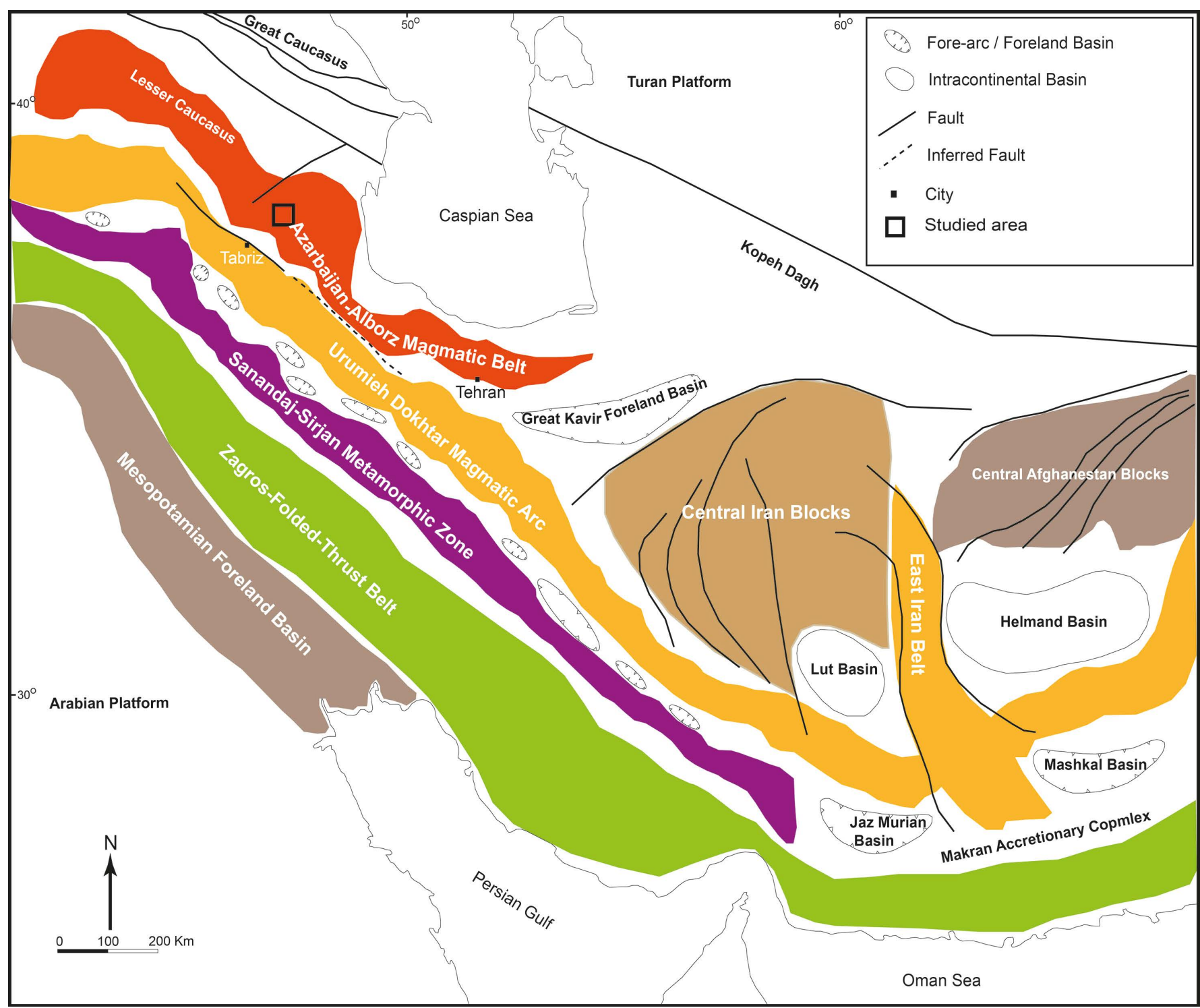

Figure 1. Location of the studied area in the important Iranian structural-magmatic zones (simplified from the tectonic map of Middle East [21]).

The mineralogy and petrography were investigated by polarized-light microscopy of thin sections. Ten whole rock powder sample of appropriate shales as random and oriented mounts were analyzed by X-ray powder diffraction (XRD) at the Geological Survey of NW Iran, Tabriz Center. XRD analyses were carried out by a Siemens D-5000 instrument with $\mathrm{Cu}-\mathrm{Ka}$ radiation. The samples were saturated with $\mathrm{K}$ and $\mathrm{Mg}$ and solvated by ethylene-glycol and heated to $550^{\circ} \mathrm{C}$ to distinguish the expandable mineral phases. The analytical results are presented in Table 1.

For major element analysis, whole-rock powders of ten samples were fused with $\mathrm{Li}_{2} \mathrm{~B}_{4} \mathrm{O}_{7}$ and analyzed on fused discs by X-ray fluorescence spectrometer (XRF) at the Kansaran Binaloud Company lab (Iran). The analytical results are presented in Table 2. Trace elements, including rare-earth elements (REE), were determined by inductively 

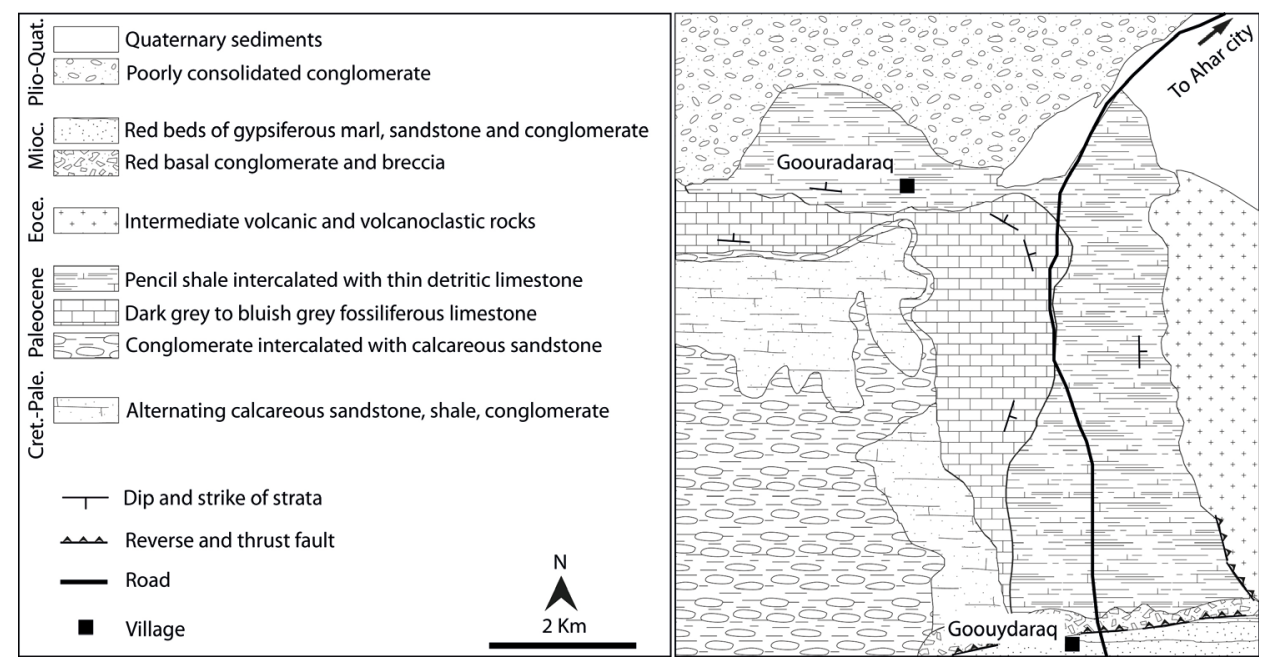

Figure 2. Geological map of the studied area (simplified from [23]).

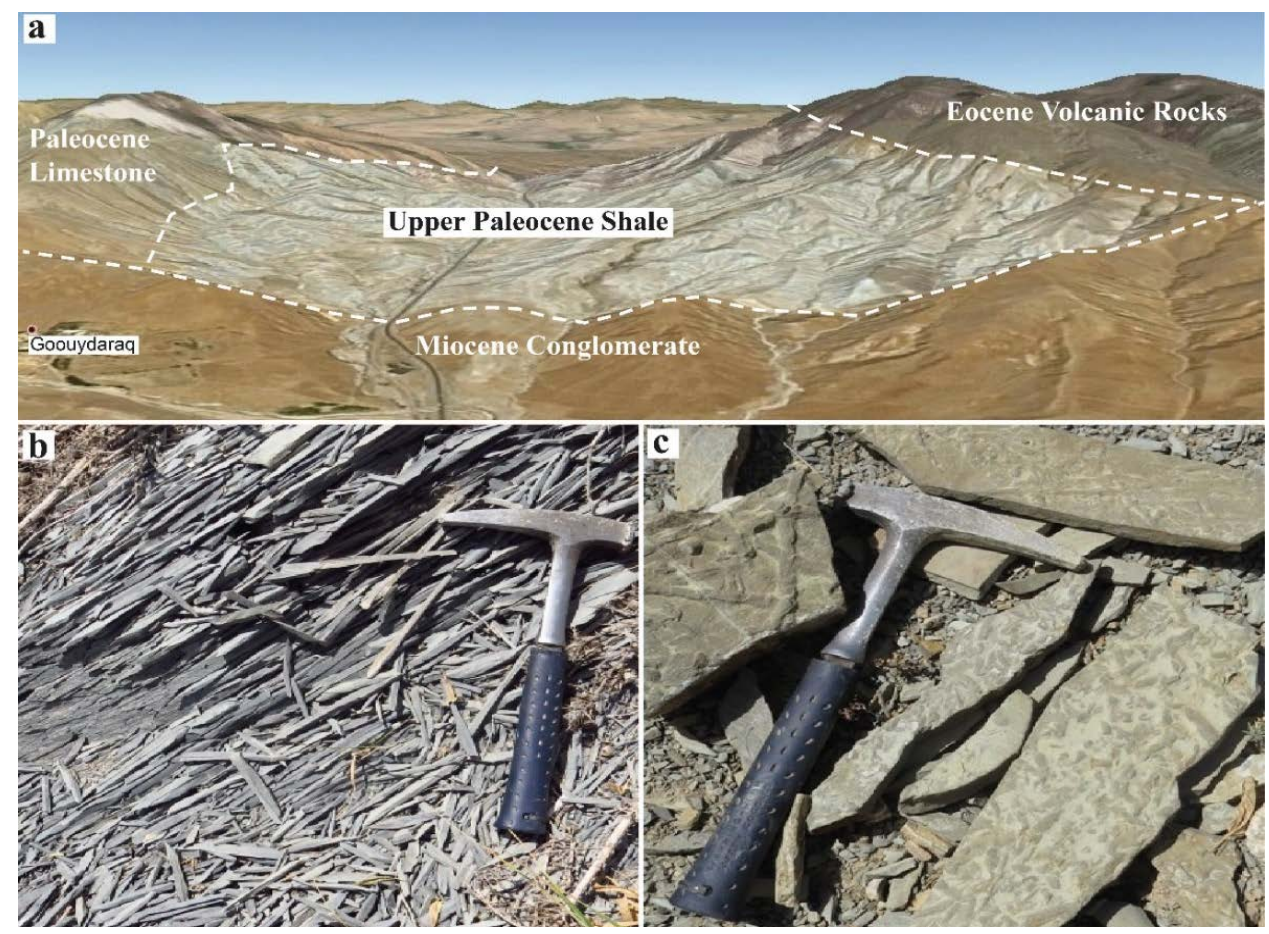

Figure 3. The photos of field observations; (a) Lithologic units around the Upper Paleocene shale (the GG shale) in the satellite image adoption from the Google Earth; (b) Pencil structure in the GG shale; (c) bioturbation traces in the studied rocks.

coupled plasma-mass spectrometer (ICP-MS) at the same lab. The analytical results of five samples are presented in Table 3.

\section{Results}

\subsection{Optical Microscopy Determinations}

The shale samples are characterized by very fine-grained texture and mainly composed 
Table 1. XRD analytical results of the GG shale including type and percent of minerals in the samples. Abbreviation symbols are Ch, Chlorite; Il, Illite; Ka, Kaolinite; Mm, montmorilonite; Pa, Palygorskite.

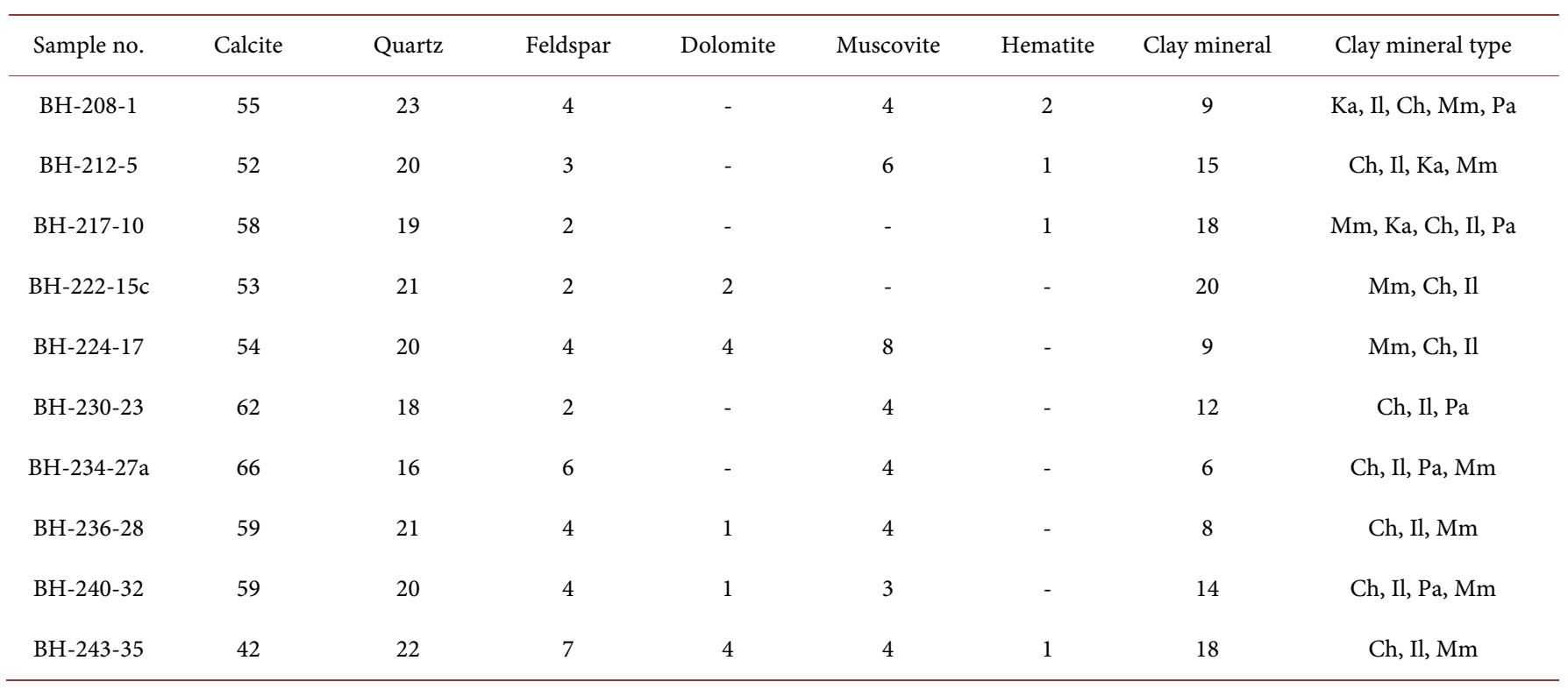

Table 2. Major element concentrations of the GG shale in wt $\%$ with some important geochemical parameters.

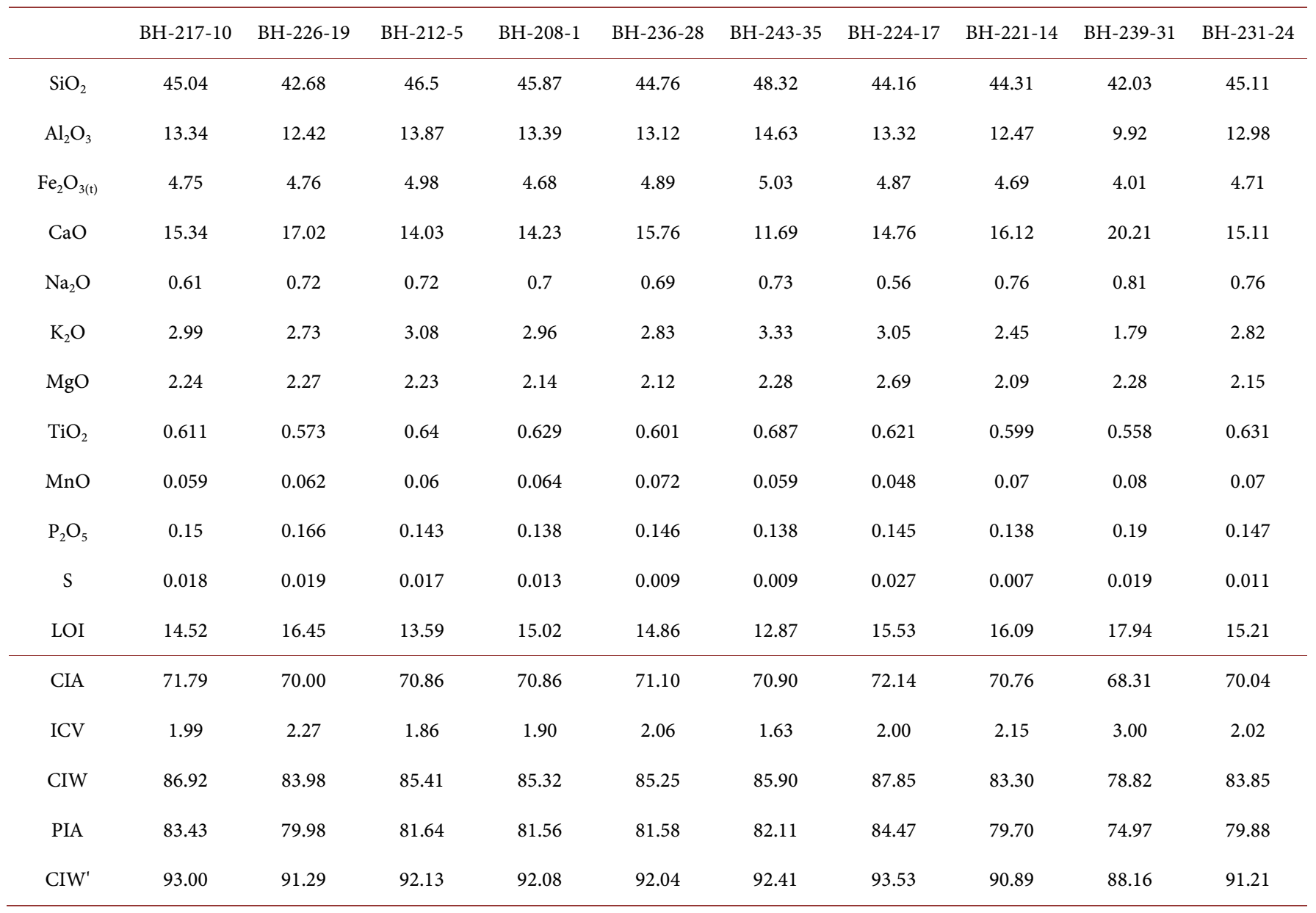


Table 3. Trace and rare earth elements concentrations in ppm for the GG shale; detection limit of elements are presented in parenthesis.

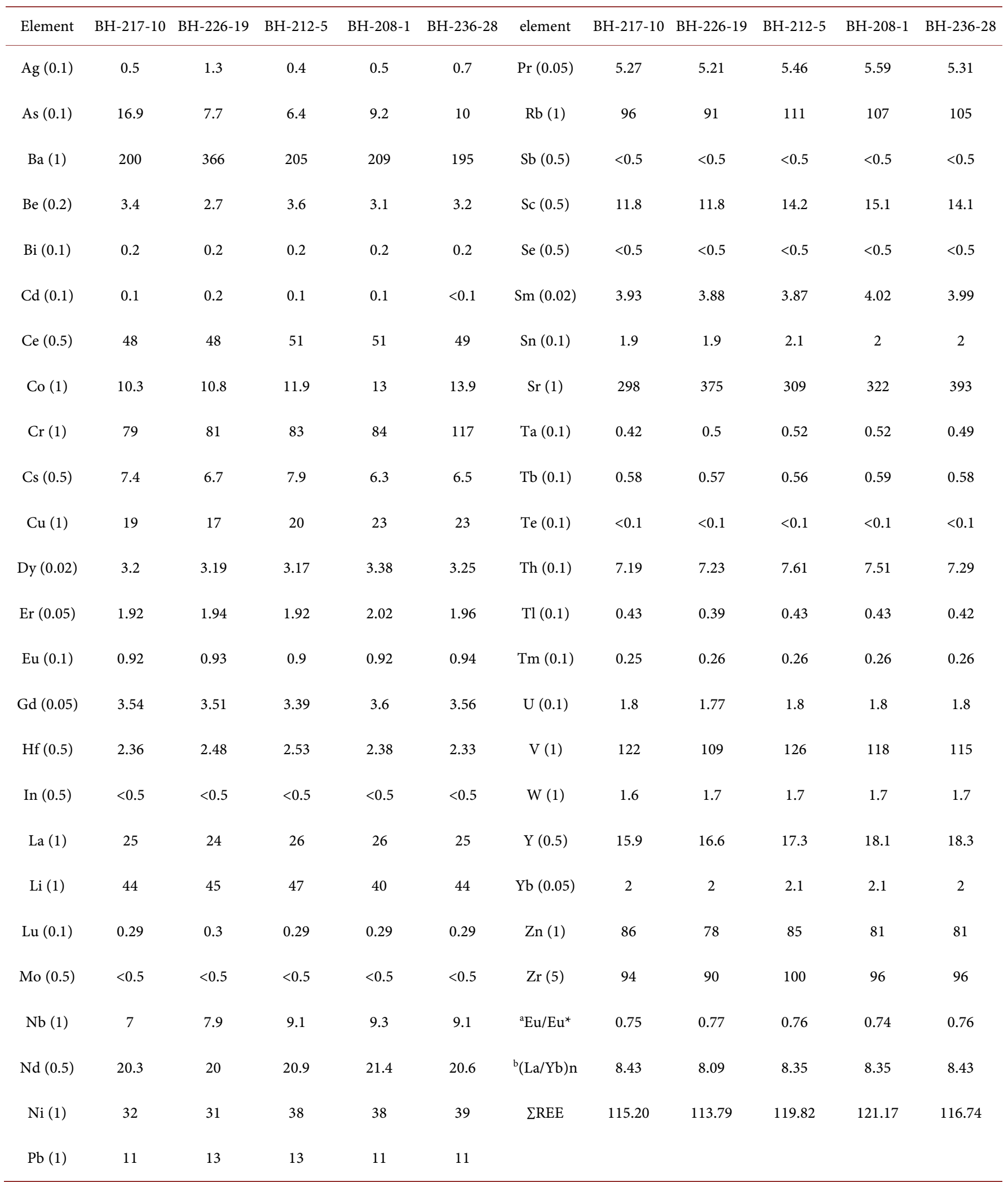

${ }^{\mathrm{a}} \mathrm{Eu} / \mathrm{Eu}^{*}=\mathrm{EuN} / \sqrt{ }[(\mathrm{SmN}) .(\mathrm{GdN})]$ as Taylor and McLennan [24] recommended; ${ }^{\mathrm{b}} \mathrm{Chondrite} \mathrm{values} \mathrm{for} \mathrm{normalizing} \mathrm{from} \mathrm{[25].}$ 
of carbonate and clay minerals as well lesser amount of fossil allochems (e.g., Globigerina sp. and Discocyclina sp.) (Figure 4(a)). The interbedded siltstones are composed of calcite, mono-crystalline quartz (10\% - 15\%), clay minerals, chlorite, muscovite, biotite, opaque minerals, plagioclase, and zircon (Figure 4(b)).

\subsection{XRD Investigations}

Whole rock and clay fraction mineral analyses of the GG shale samples are listed in $\mathrm{Ta}$ ble 1 . All samples consist of calcite $(42 \%-66 \%)$, quartz ( $16 \%-23 \%)$, clay minerals $(6 \%$ - 20\%), feldspar (2\% - 7\%), muscuvite, dolomite, hematite and opal. Clay minerals are composed of chlorite, illite, montnorilonite, kaolinite, and palygorskite. A representative XRD pattern of air-dried Mg- and K-saturated, glycol-treated and heated samples are shown in Figure 5. Montmorillonite is easily identified by comparing diffraction patterns of air-dried and ethylene glycol-solvated preparations. Montmorillonite is characterized by (001) peak at about $9.9 \AA$. this peak is weak after glycol treatment. Chlorite has a basal series of diffraction peaks based on a first-order reflection of 14.3 $\AA$ A. Also helpful identification of chlorite is provided by peaks at 6.2 and $25.1^{\circ} 2 \theta$. Kaolinite has reflections based on a $7.1 \AA$ structure which that is disappeared at heated $550^{\circ} \mathrm{C}$ [26]. The XRD pattern shows the (001) peak at about $9.9 \AA$ for illite and (001) peak at about $10.8 \AA$ for palygorskite.

\subsection{Geochemical Properties}

\subsubsection{Major and Trace Elements}

Major and trace elements concentrations of the studied samples are listed in Table 2 and Table 3. Geochemical classification of the study samples by diagram of Herron [27], $\log \left(\mathrm{SiO}_{2} / \mathrm{Al}_{2} \mathrm{O}_{3}\right)$ versus $\log \left(\mathrm{Fe}_{2} \mathrm{O}_{3} / \mathrm{K}_{2} \mathrm{O}\right)$, indicates shale composition (Figure 6(a)) [27]. The $\mathrm{CaO}$ content of samples varies from 11.69 to 20.21 and in average they have higher $\mathrm{CaO}$ content in comparison to the Archean Shales (AS), post-Archean Astralian Shales (PAAS), and North American Shale Composite (NASC). However the GG shale samples have lower contents of $\mathrm{Al}_{2} \mathrm{O}_{3}, \mathrm{SiO}_{2}$, and $\mathrm{Fe}_{2} \mathrm{O}_{3}$ in comparison to the standard shales (Figure 6(b)).
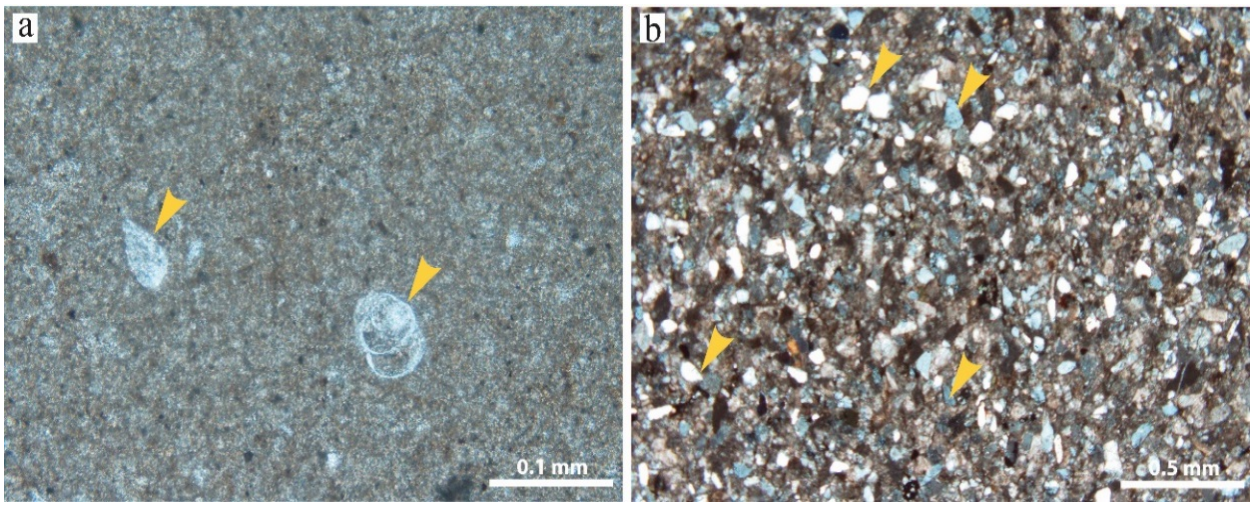

Figure 4. The microscopic photos; (a) Globigerina sp. microfossil in the shale; (b) angular monocrystalline quartz grains in the intercalated siltstone. 

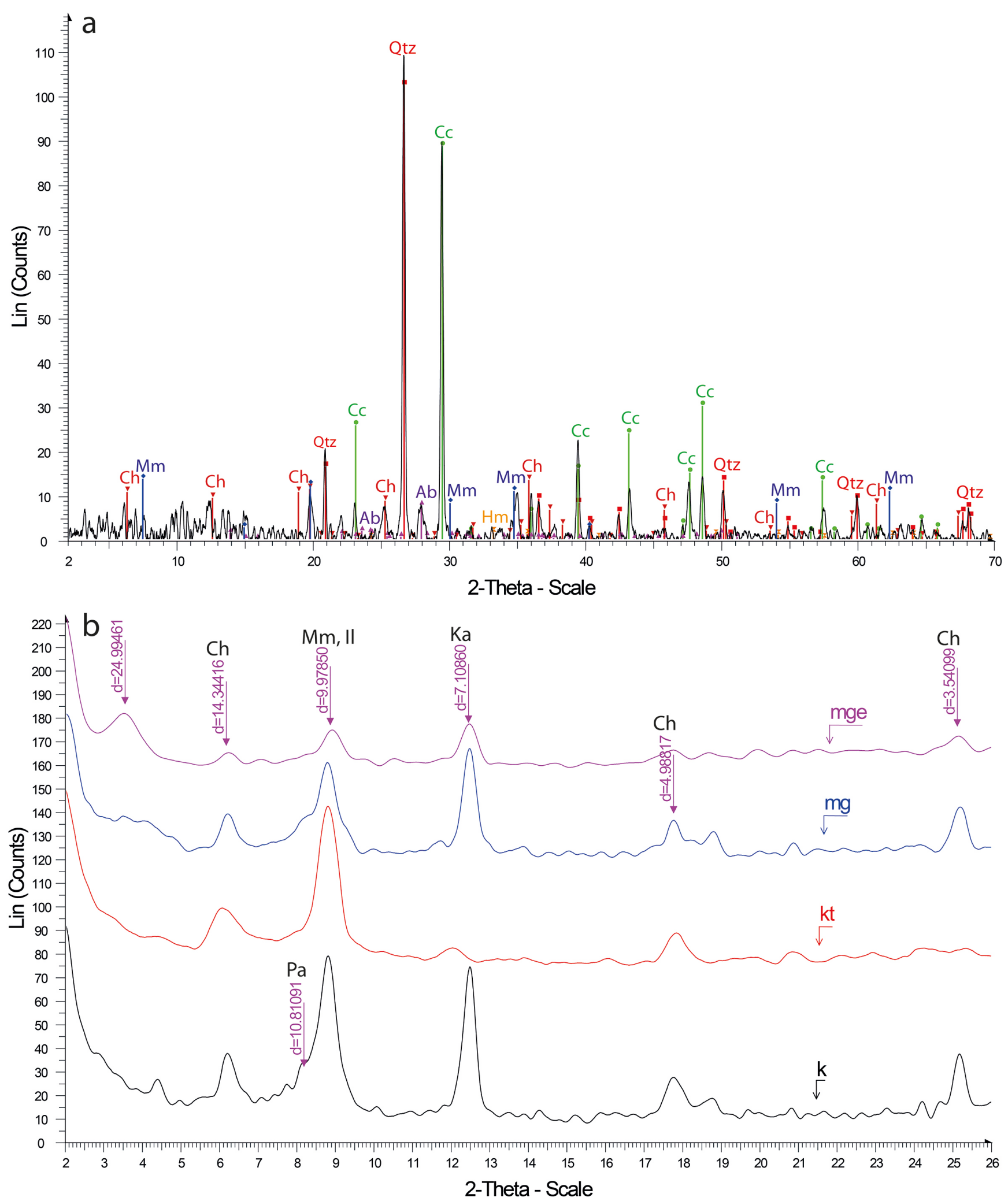

Figure 5. Representative XRD patterns of sample BH-217-10 (a) Qtz, Quartz; Cc, Calcite; Ab, Albite; Ch, Chlorite; Mm, montmorillonite; $\mathrm{Hm}$, Hematite. (b) k, K-saturated; kt, K-saturated and heated at $550^{\circ} \mathrm{C}$; mg, Mg-saturated; mge, treated with $\mathrm{Mg}$ and ethylene-glycol; Mm, montmorillonite; Ka, Kaolinite; Ch, Chlorite; Il, Illite; Pa, Palygorskite. 

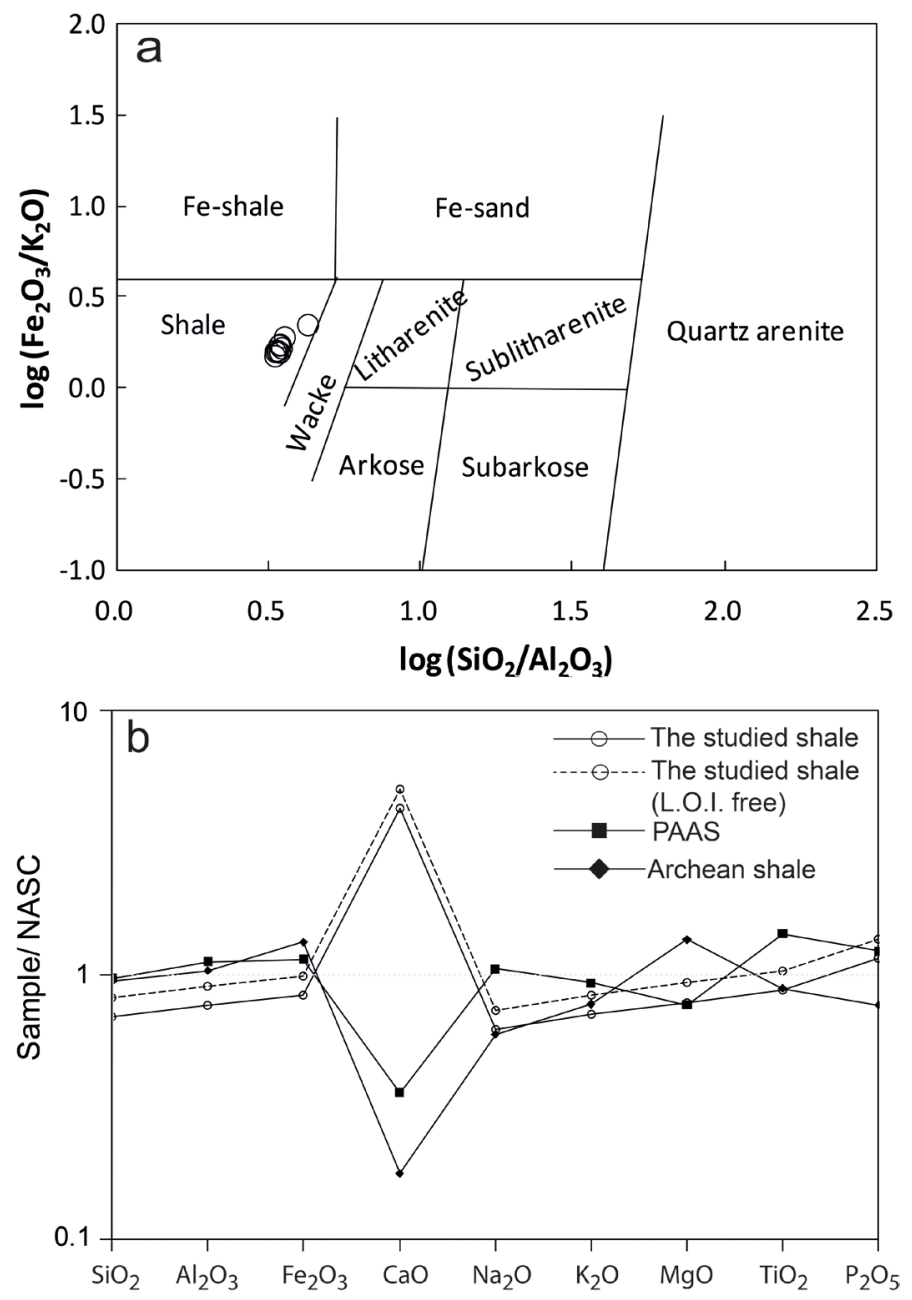

Figure 6. (a) Classification of the GG shale based on the diagram of Herron [27], $\log \left(\mathrm{SiO}_{2} / \mathrm{Al}_{2} \mathrm{O}_{3}\right)$ versus $\log \left(\mathrm{Fe}_{2} \mathrm{O}_{3} / \mathrm{K}_{2} \mathrm{O}\right)$; (b) NASC normalized major oxides for the studied shales compared with PAAS and AS; the normalized and compared data are from [28].

A linear regression and correlation analysis was performed to reveal any communality of minerals and elements by Excel and Minpet 2.02 softwares (Table 4 and Table 5). Some correlation plots for major and trace elements are shown in Figure 7. $\mathrm{SiO}_{2}$ is positively correlated with $\mathrm{Al}_{2} \mathrm{O}_{3}, \mathrm{~K}_{2} \mathrm{O}$, and $\mathrm{TiO}_{2}(\mathrm{r}=0.80$ - 0.96) and negatively correlated with $\mathrm{CaO}(\mathrm{r}=-0.93)$ and $\mathrm{P} 2 \mathrm{O} 5(\mathrm{r}=-0.77)$. This suggests that $\mathrm{CaO}$ is derived primarily from carbonates, but other elements are associated with silicates. LOI (loss on ignition) is positively correlated with $\mathrm{CaO}(\mathrm{r}=0.93)$ and negatively correlated with $\mathrm{SiO}_{2}, \mathrm{Al}_{2} \mathrm{O}_{3}$, $\mathrm{K}_{2} \mathrm{O}$, and $\mathrm{TiO}_{2}(\mathrm{r}>0.90) . \mathrm{SiO}_{2}$ and $\mathrm{Al}_{2} \mathrm{O}_{3}$ show positive correlations with $\mathrm{Zr}, \mathrm{V}$, and $\mathrm{Rb}$ $(\mathrm{r}>0.83)$.

The Cs and Sr content of samples vary from 6.3 to 7.9 and 298 to $393 \mathrm{ppm}$ respectively which have higher contents in comparison to the NASC (Figure 8(a)); whereas other trace elements such as $\mathrm{Ba}, \mathrm{Hf}, \mathrm{Zr}, \mathrm{Co}, \mathrm{Y}$, and $\mathrm{Ta}$ have lower contents than the NASC. 

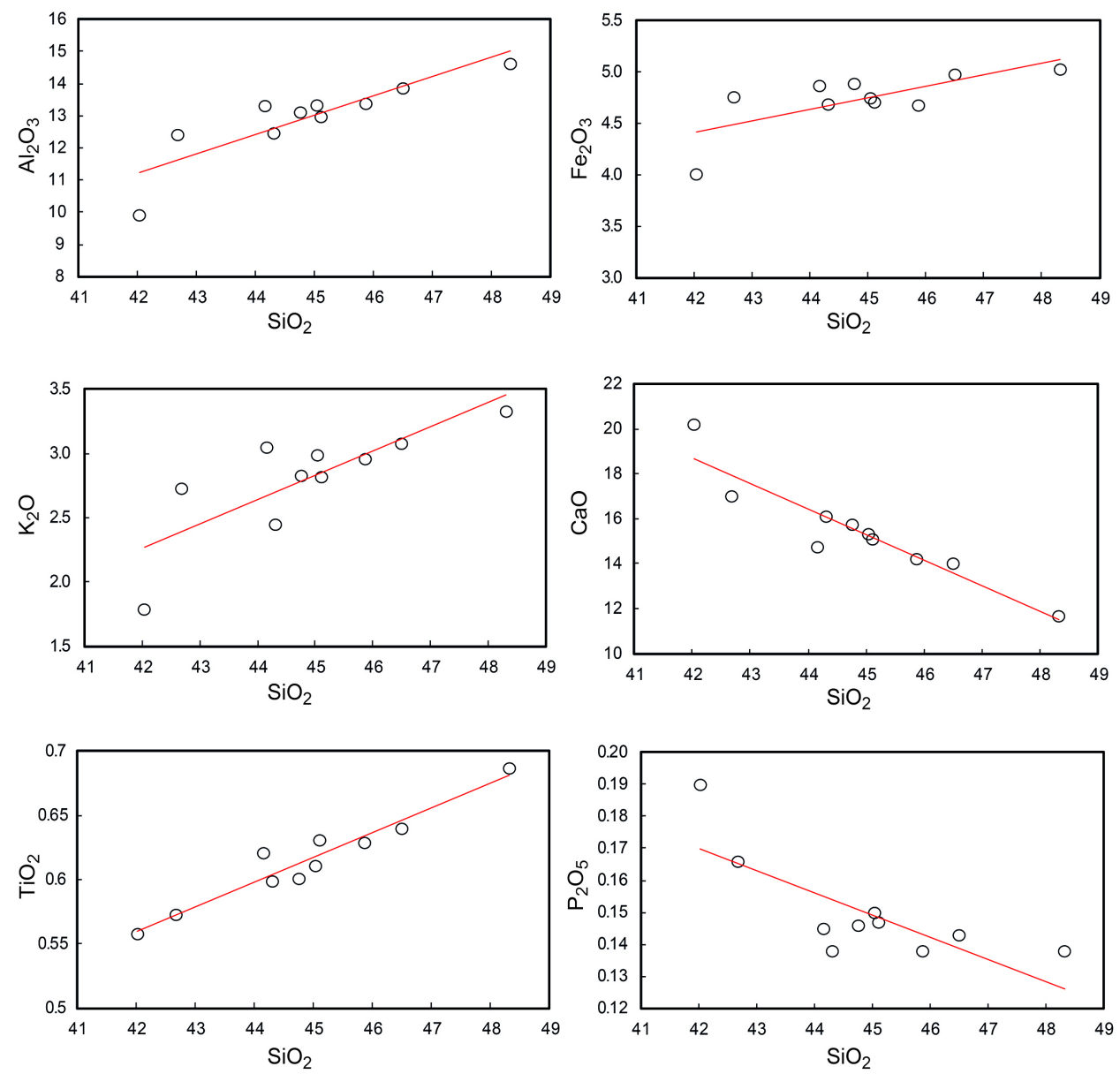

Figure 7. Harker variation diagram of major oxides for the GG shale samples.

Table 4. Values of the correlation coefficient ( $r$ ) for the major oxides of samples.

\begin{tabular}{|c|c|c|c|c|c|c|c|c|c|c|}
\hline & $\mathrm{SiO}_{2}$ & $\mathrm{TiO}_{2}$ & $\mathrm{Al}_{2} \mathrm{O}_{3}$ & $\mathrm{Fe}_{2} \mathrm{O}_{3}$ & $\mathrm{MnO}$ & $\mathrm{MgO}$ & $\mathrm{CaO}$ & $\mathrm{Na}_{2} \mathrm{O}$ & $\mathrm{K}_{2} \mathrm{O}$ & $\mathrm{P}_{2} \mathrm{O}_{5}$ \\
\hline LOI & -0.95 & -0.91 & -0.94 & -0.84 & 0.52 & 0.06 & 0.93 & 0.31 & -0.9 & 0.76 \\
\hline $\mathrm{P}_{2} \mathrm{O}_{5}$ & -0.77 & -0.75 & -0.87 & -0.82 & 0.5 & 0.13 & 0.87 & 0.38 & -0.78 & \\
\hline $\mathrm{K}_{2} \mathrm{O}$ & 0.8 & 0.82 & 0.98 & 0.92 & -0.77 & 0.18 & -0.94 & -0.58 & & \\
\hline $\mathrm{Na}_{2} \mathrm{O}$ & -0.13 & -0.2 & -0.48 & -0.49 & 0.81 & -0.63 & 0.37 & & & \\
\hline $\mathrm{CaO}$ & -0.93 & -0.95 & -0.97 & -0.87 & 0.64 & -0.06 & & & & \\
\hline $\mathrm{MgO}$ & -0.15 & 0.05 & 0.05 & 0.09 & -0.67 & & & & & \\
\hline $\mathrm{MnO}$ & -0.39 & -0.51 & -0.69 & -0.68 & & & & & & \\
\hline $\mathrm{Fe}_{2} \mathrm{O}_{3}$ & 0.71 & 0.71 & 0.94 & & & & & & & \\
\hline $\mathrm{Al}_{2} \mathrm{O}_{3}$ & 0.87 & 0.87 & & & & & & & & \\
\hline $\mathrm{TiO}_{2}$ & 0.96 & & & & & & & & & \\
\hline
\end{tabular}


Table 5. Values of correlation coefficient ( $r$ ) between the major and minor elements of samples.

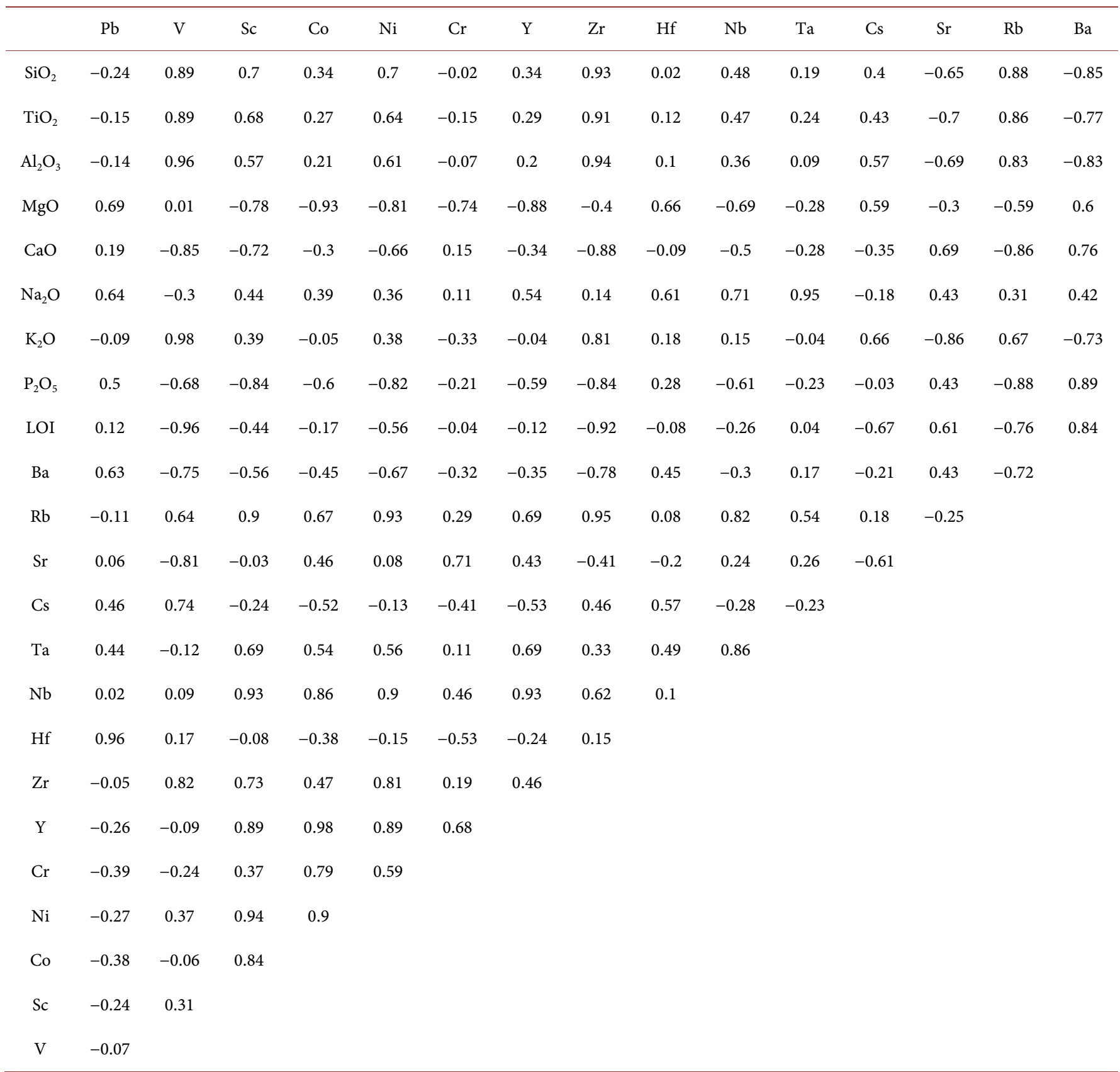

\subsubsection{Rare Earth Elements}

REE concentrations of five samples of the studied shales are shown in Table 3. A chondrite-normalized [25], REE diagram for the studied shale was compared with Chondrite-normalized REE patterns of PAAS, AS, and NASC (Figure 8(b)). The mean total REE content of the GG shale in comparison to the PAAS, NASC, and AS is lower $(\Sigma \mathrm{REE}=117.34 \mathrm{ppm})$. However, the Chondrite-normalized REE patterns show no major difference among all the shales (Figure $8(\mathrm{~b})$ ). All of them have high LREE/HREE and $\mathrm{Eu}$ anolmalies. In average the GG shale have $(\mathrm{La} / \mathrm{Yb}) \mathrm{N}=8.33$ and $\mathrm{Eu} / \mathrm{Eu}^{*}=0.76$. 

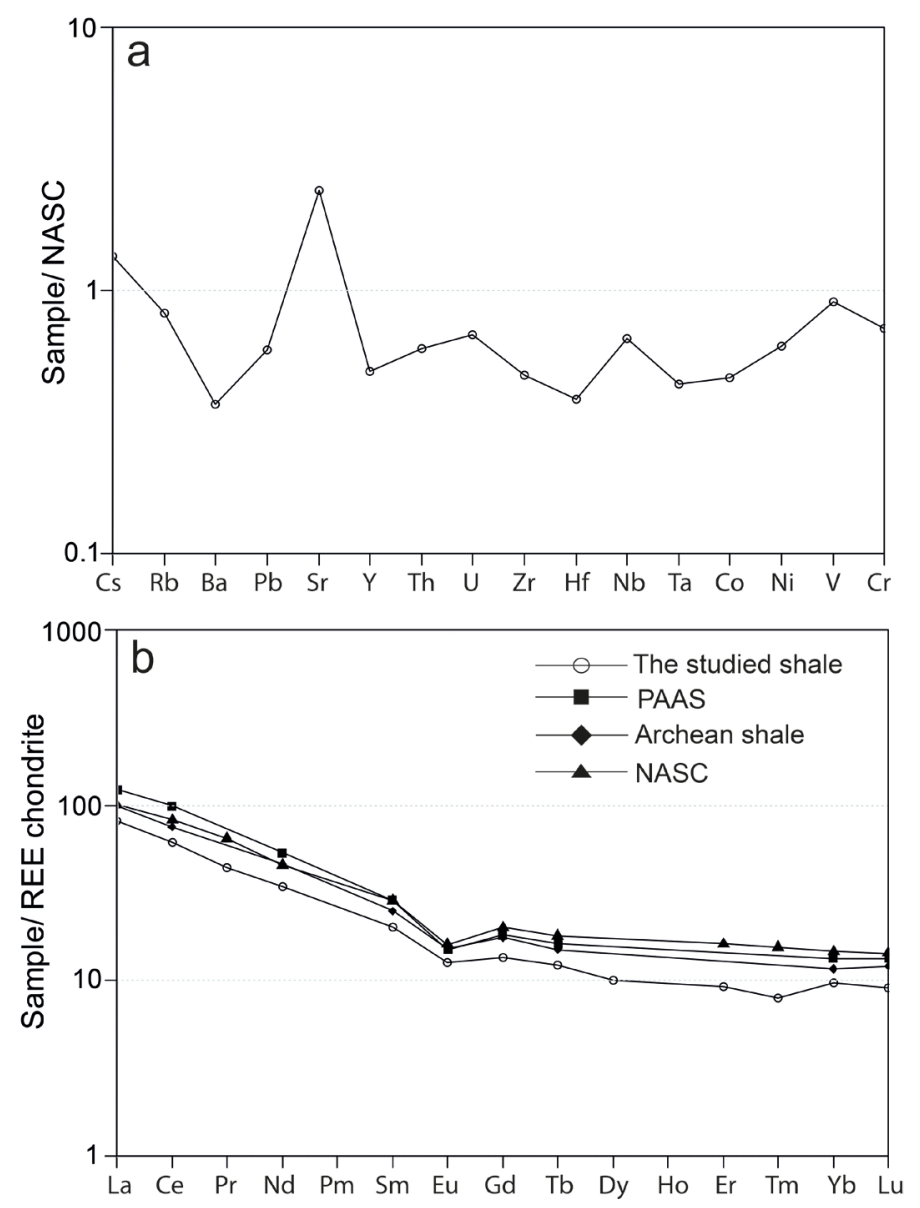

Figure 8. (a) the pattern of NASC normalized trace elements for the studied shales; (b) Chondrite normalized REE for the studied shales compared with Chondrite normalized REE patterns for PAAS, AS, and NASC. The values of REE for the standard shales are from [28] and [29], and for chondrite are from [25].

\subsection{Source Rocks and Tectonic Setting}

A discriminant function diagram has been proposed by [3] to distinguish between sediments whose provenance is primarily mafic, intermediate or felsic igneous and quartzose sedimentary. The discriminant functions are based upon the ratios of $\mathrm{TiO}_{2}$, $\mathrm{Fe}_{2} \mathrm{O}_{3}(\mathrm{t}), \mathrm{MgO}, \mathrm{Na}_{2} \mathrm{O}$, and $\mathrm{K}_{2} \mathrm{O}$ all to $\mathrm{Al}_{2} \mathrm{O}_{3}$ (Figure 9(a)). All the samples are plotted in quartzose sedimentary field however they are near intermediate igneous field.

$\mathrm{Na}, \mathrm{K}, \mathrm{Ca}$ and $\mathrm{Mg}$ concentrations are enriched/depleted by weathering, transportation from the source rock to the depositional site and diagenesis, whereas $\mathrm{Ti}, \mathrm{Al}, \mathrm{Zr}$ remain unaffected because of low solubility of their oxides and hydroxides in low temperature aqueous solutions [30]-[32]. The ratio of $\mathrm{Al}_{2} \mathrm{O}_{3} / \mathrm{TiO}_{2}$ in shales is similar to that of the parent rocks [32]. Therefore, the $\mathrm{Al}_{2} \mathrm{O}_{3} / \mathrm{TiO}_{2}$ ratio is used as a significant indicator of source rocks compared to other major oxides. The $\mathrm{Al}_{2} \mathrm{O}_{3} / \mathrm{TiO}_{2}$ ratios of the GG shales range from 17.78 to 21.83 (Table 2). Most of the samples exhibit higher $\mathrm{Al}_{2} \mathrm{O}_{3} / \mathrm{TiO}_{2}$ values $(\approx 21)$, corresponding to felsic (and/or intermediate) source rocks [32]. 

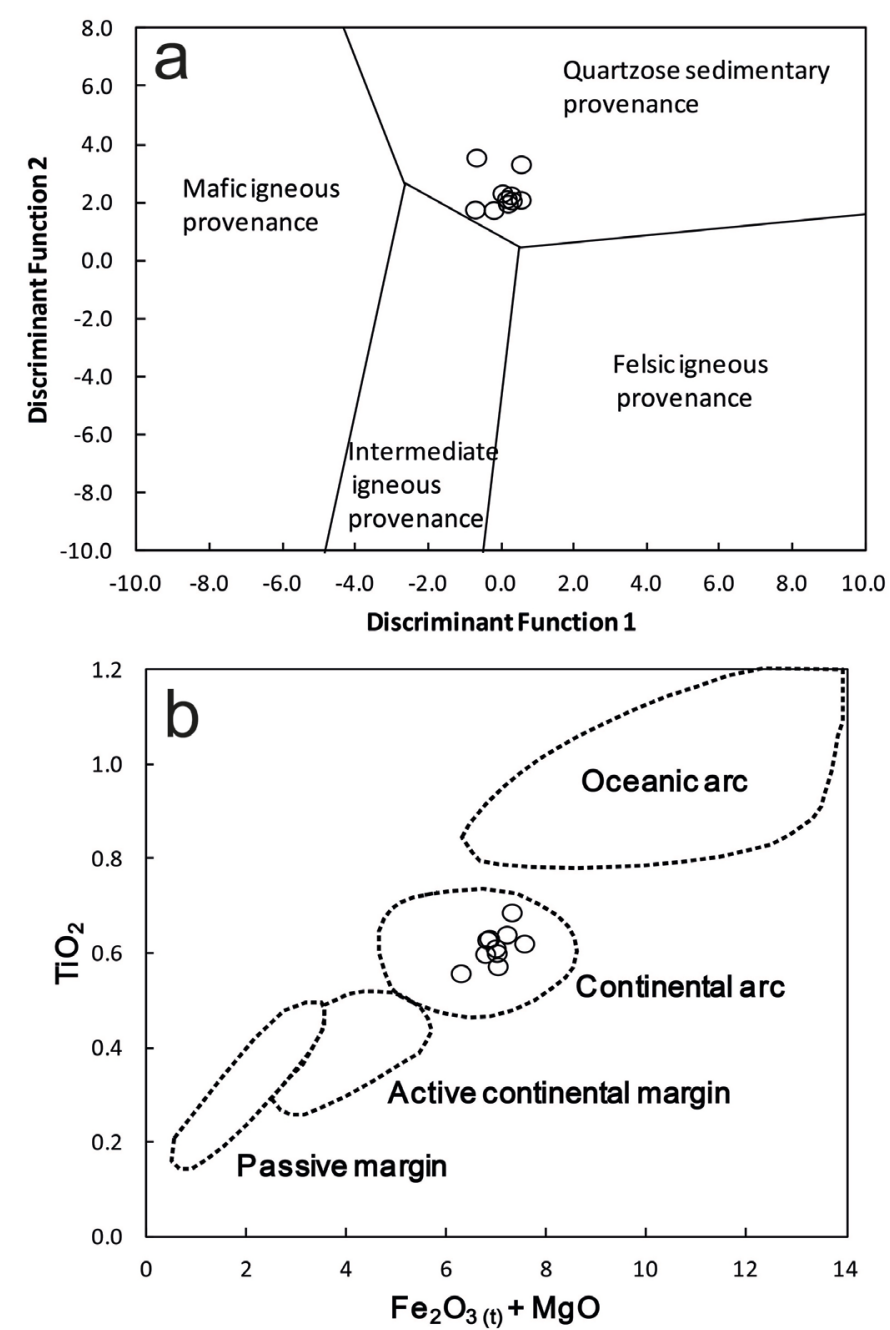

Figure 9. (a) Plot of discriminant scores along Function 1 versus Function 2 diagram [3] to discriminate provenance signatures of the GG shale; Discrimination Function 1: $30.638 \mathrm{TiO}_{2} / \mathrm{Al}_{2} \mathrm{O}_{3}$ - 12.541 $\mathrm{Fe}_{2} \mathrm{O}_{3}(\mathrm{t}) / \mathrm{Al}_{2} \mathrm{O}_{3}+7.329 \mathrm{MgO} / \mathrm{Al}_{2} \mathrm{O}_{3}+12.031 \mathrm{Na}_{2} \mathrm{O} / \mathrm{Al}_{2} \mathrm{O}_{3}+35.402 \mathrm{~K} \mathrm{O}_{2} / \mathrm{Al}_{2} \mathrm{O}_{3}-6.382$, Discrimination Function 2: $56.500 \mathrm{TiO}_{2} / \mathrm{Al}_{2} \mathrm{O}_{3}-10.879 \mathrm{Fe}_{2} \mathrm{O}_{3}(\mathrm{t}) / \mathrm{Al}_{2} \mathrm{O}_{3}+30.875 \mathrm{MgO} / \mathrm{Al}_{2} \mathrm{O}_{3}-$ $5.404 \mathrm{Na}_{2} \mathrm{O} / \mathrm{Al}_{2} \mathrm{O}_{3}+11.112 \mathrm{~K}_{2} \mathrm{O} / \mathrm{Al}_{2} \mathrm{O}_{3}-3.89$; (b) Major element composition plots of the GG shale for tectonic setting discrimination. Plot of $\mathrm{Fe}_{2} \mathrm{O}_{3}(\mathrm{t})+\mathrm{MgO}$ versus $\mathrm{TiO}_{2}$ [33]. $\mathrm{Fe}_{2} \mathrm{O}_{3}(\mathrm{t})$ represents total iron.

The major and trace element geochemistry of detrital sedimentary rocks can be used to infer provenance type and the tectonic setting ancient sedimentary basins [1] [33]. A plot involving $\mathrm{Fe}_{2} \mathrm{O}_{3}(\mathrm{t})+\mathrm{MgO}$ versus $\mathrm{TiO}_{2}$ is used to discriminate between shales deposited in passive margin, active continental margin, continental island arc and oceanic island arc settings [33]. It is found from this plot (Figure 9(b)) that all the GG shale samples are plotted in continental arc setting field. Meanwhile the content of trace elements $(\mathrm{Th}=7.36$ and $\mathrm{La}=25.2 \mathrm{ppm})$ as well the elemental ratios $(\mathrm{Ti} / \mathrm{Zr}=38, \mathrm{Th} / \mathrm{Sc}=$ $0.55, \mathrm{La} / \mathrm{Sc}=1.8$, and $\mathrm{La} / \mathrm{Th}=3.4)$ suggest a continental arc setting for the GG shale (Table 6). Also the ternary diagram of Th-Sc-Zr/10 [1] show that all the GG shales are plotted within the continental island arc field (Figure 10(a)). 

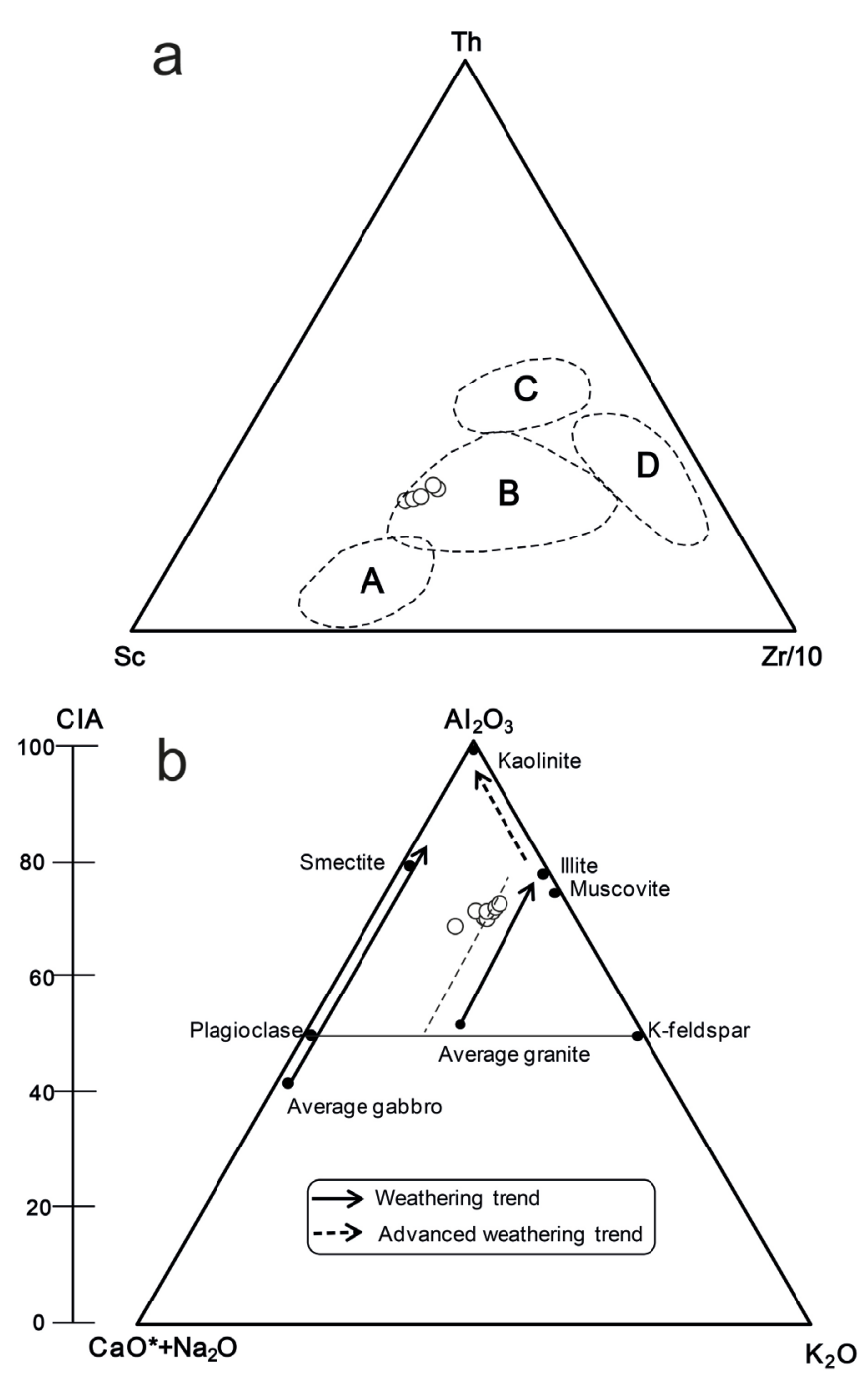

Figure 10. (a) The chemical composition of GG shale on Th-Sc-Zr/10 diagram [1] for discrimination of various tectonic setting, A: Oceanic island arc; B: Continental island arc; C: Active continental margins; D: Passive margins. (b) $\mathrm{Al}_{2} \mathrm{O}_{3}-\left(\mathrm{CaO}+\mathrm{Na}_{2} \mathrm{O}\right)-\mathrm{K}_{2} \mathrm{O}$ diagram and CIA (chemical index of alteration) for evaluation of the weathering trend of the GG shale. Arrows show predicted weathering trend of some references compositions including gabbro and granite. The diagram also represents the fields of idealized minerals [6] [34] [35].

\subsection{Paleoweathering Conditions in the Provenance}

There are various parameters for determining source rock weathering. The Chemical Index of Alteration (CIA) values and A-CN-K compositional space are reliable indicators of paleoweathering and tectonic history of sedimentary rocks. The CIA was proposed by [34] [37] as a way of investigating the intensity of chemical weathering in a source area. $\mathrm{CIA}=\left[\mathrm{Al}_{2} \mathrm{O}_{3} /\left(\mathrm{Al}_{2} \mathrm{O}_{3}+\mathrm{CaO}^{\star}+\mathrm{K}_{2} \mathrm{O}+\mathrm{Na}_{2} \mathrm{O}\right)\right] \times 100$.

Values are expressed as molar proportions and $\mathrm{CaO}^{*}$ represents $\mathrm{CaO}$ present in silicate minerals only. The $\mathrm{CaO}^{*}$ concentration was calculated based on [38]. CIA values for the samples vary from 68 to 72 (Table 2) which that suggests moderate weathering in the source area. 
Table 6. The comparison of trace and rare earth elements characteristics of the GG shale with gray wakes and mudrocks from various tectonic settings as well some geochemical parameters [1] [36]; Mean ratios and contents were obtained from five samples.

\begin{tabular}{|c|c|c|c|c|c|}
\hline $\begin{array}{l}\text { Element in ppm/ } \\
\text { Elemental ratio }\end{array}$ & $\begin{array}{l}\text { Oceanic } \\
\text { island arc }\end{array}$ & $\begin{array}{l}\text { Continental } \\
\text { island arc }\end{array}$ & $\begin{array}{c}\text { Active } \\
\text { continental } \\
\text { margins }\end{array}$ & $\begin{array}{l}\text { Passive } \\
\text { margins }\end{array}$ & GG Shale \\
\hline $\mathrm{Zr} / \mathrm{Th}$ & 48 & - & 9.5 & - & 12.9 \\
\hline $\mathrm{Th} / \mathrm{U}$ & 2.1 & - & - & - & 4.1 \\
\hline $\mathrm{La} / \mathrm{Y}$ & 0.5 & - & - & - & 1.4 \\
\hline $\mathrm{Ti} / \mathrm{Zr}$ & 57 & 20 & 15 & 6.7 & 38 \\
\hline $\mathrm{Th} / \mathrm{Sc}$ & 4.3 & 0.85 & 2.6 & 3.1 & 0.55 \\
\hline $\mathrm{La} / \mathrm{Sc}$ & - & 1.8 & 4.5 & 6.2 & 1.9 \\
\hline $\mathrm{La} / \mathrm{Th}$ & - & 2.3 & 1.7 & - & 3.4 \\
\hline $\mathrm{La}$ & $8 \pm 1.7$ & $27 \pm 4.5$ & 37 & 39 & 25 \\
\hline $\mathrm{Ce}$ & $19 \pm 3.7$ & $59 \pm 8.2$ & 78 & 85 & 49 \\
\hline$\Sigma \mathrm{REE}$ & $58 \pm 10$ & $146 \pm 20$ & 186 & 210 & 117 \\
\hline $\mathrm{La} / \mathrm{Yb}$ & $4.2 \pm 1.3$ & $11 \pm 3.6$ & 12.5 & 15.9 & 12.3 \\
\hline$(\mathrm{La} / \mathrm{Yb})_{\mathrm{N}}$ & $2.8 \pm 0.9$ & $7.5 \pm 2.5$ & 8.5 & 10.8 & 8.3 \\
\hline$\Sigma$ LREE/ $\Sigma$ HREE & $3.8 \pm 0.9$ & $7.7 \pm 1.7$ & 9.1 & 8.5 & 8.9 \\
\hline $\mathrm{Eu} / \mathrm{Eu}^{*}$ & $1.04 \pm 0.11$ & $0.79 \pm 0.13$ & 0.60 & 0.56 & 0.76 \\
\hline
\end{tabular}

As K-metasomatism may possibly reduce the CIA values, many researchers used Plagioclase Index of Alteration, PIA $=\left[\left(\mathrm{Al}_{2} \mathrm{O}_{3}-\mathrm{K}_{2} \mathrm{O}\right) /\left(\mathrm{Al}_{2} \mathrm{O}_{3}-\mathrm{K}_{2} \mathrm{O}+\mathrm{CaO}^{*}+\mathrm{Na}_{2} \mathrm{O}\right)\right] \times 100$, and Chemical Index of Weathering, $\mathrm{CIW}=\left[\mathrm{Al}_{2} \mathrm{O}_{3} /\left(\mathrm{Al}_{2} \mathrm{O}_{3}+\mathrm{CaO}^{*}+\mathrm{Na}_{2} \mathrm{O}\right)\right] \times 100$, for better estimation of weathering conditions in the source rocks e.g. [6] [39]. The PIA and CIW values for the GG shale range from 74 to 84 and 78 to 87 respectively (Table 2). The data indicate a greater degree of weathering of source rocks than the degree of weathering inferred from their CIA values. As interpreted from the CIA discussions, the PIA and CIW data for the shales also support a moderate degree of weathering of the source rocks.

The Index of Compositional Variability, ICV $=\left(\mathrm{Fe}_{2} \mathrm{O}_{3}+\mathrm{K}_{2} \mathrm{O}+\mathrm{Na}_{2} \mathrm{O}+\mathrm{CaO}+\mathrm{MgO}\right.$ $\left.+\mathrm{TiO}_{2}\right) / \mathrm{Al}_{2} \mathrm{O}_{3}$, may be used to assess the original composition of shales and siltstones [17]. The non-clay minerals in the original rocks have higher values of ICV's than do the clay minerals. In relatively unaltered shales and siltstones, composed mostly of feldspar, pyroxene, amphibole, or biotite with less abundant clay minerals, ICV value tend to be greater than one. The ICV values for the GG shale range from 1.63 to 3 .

Weathering as well as post-depositional diagenetic history of clastic sediments can be evaluated by plotting the CIA values in A-CN-K compositional space (Figure 10(b)). 
In A-CN-K compositional space $\left(\mathrm{A}=\mathrm{Al}_{2} \mathrm{O}_{3}, \mathrm{CN}=\mathrm{CaO}+\mathrm{Na}_{2} \mathrm{O}, \mathrm{K}=\mathrm{K}_{2} \mathrm{O}\right)$ the oxides are represented in molar proportions [34] [35] [40]-[42]. In this diagram, during initial stages of weathering the trends are parallel to the A-CN line, because during that stage $\mathrm{Na}$ and $\mathrm{Ca}$ are removed with destruction of plagioclase feldspars (a solid arrow starting from the gabbro composition in (Figure 10(b)). As weathering continues, K-feldspars are destroyed releasing $\mathrm{K}$ and shifting the residual composition towards $\mathrm{Al}_{2} \mathrm{O}_{3}$. None of the samples plot near the $\mathrm{Al}_{2} \mathrm{O}_{3}-\mathrm{K}_{2} \mathrm{O}$ joins, indicating that severe weathering conditions did not exist in the source area [43]. An additional advantage of the A-CN-K compositional space is that estimation of source rock condition is possible by backward projection of the weathered samples to a point on the feldspar join. The regression line through the data points and parallel to the A-CN join is extended back to the plagioclase-K-feldspar join (dashed line in Figure 10(b)). The position of the intersection point, which provides an approximate thought of plagioclase: K-feldspar ratio of the source rock, suggested an intermediate to felsic source for the GG shale.

\section{Discussion}

Major, trace and rare earth element concentrations for the GG shale are analyzed and interpreted for the first time in this paper. The major oxide ratios suggest a quartzose sedimentary and/or intermediate igneous provenance for the studied shale (Figure 9(a)). The thin siltstone layers as interbedded with the GG shale are characterized by mono-crystalline quartz $(10 \%-15 \%)$ and parallel extinction which could be inferred a volcanic igneous provenance for the studied rocks. The $\mathrm{Al}_{2} \mathrm{O}_{3} / \mathrm{TiO}_{2}$ ratios suggest a felsic (and/or intermediate) source for the GG sediments. The rang of elemental ratios such as $\mathrm{Ti} / \mathrm{Zr}=37-39, \mathrm{Th} / \mathrm{Sc}=0.50-0.61, \mathrm{La} / \mathrm{Sc}=1.72-2.12$, and $\mathrm{Th} / \mathrm{Cr}=0.06-0.09$ for the studied samples in comparison to those of the silicic/felsic, intermediate, and basic/mafic sources [8] [32] [44] as well the chondrite normalized LREE patterns further strengthen the predominance of felsic/silicic sources for the GG shale.

The A-CN-K compositional space for the GG shales provides valuable information regarding paleoweathering, paleotectonics and source rock composition. The A-CN-K diagram suggests that severe weathering conditions did not exist in the source area and the source rock was an intermediate to felsic igneous rock. Also PIA, CIA and CIW suggest moderate climatic conditions during deposition and indicate that extreme weathering conditions were probably negligible in the source area. Shales and siltstones with ICV's greater than one are most likely first cycle sediments, and those with ICV's less than one may be recycled or intensely weathered first cycle sediment. The ICV values for the GG shale are greater than one. Such shales and siltstones are usually deposited as first cycle deposits in technically active areas [45] [46]. Meanwhile, shales and siltstones with scarce clay minerals tend to have ICV's greater than one and form in areas of most uplift and are associated with not extensive chemical weathering [17].

The elemental ratios value and the rare earth element concentrations including Th/Sc $=0.55, \mathrm{Ti} / \mathrm{Zr}=38, \mathrm{La} / \mathrm{Sc}=1.9, \mathrm{La}=25 \mathrm{ppm}$, and $\mathrm{Ce}=49 \mathrm{ppm}$ as well the geochemical parameters such as $\Sigma \mathrm{REE}=117.34, \mathrm{Eu} / \mathrm{Eu}^{*}=0.76$, and $(\mathrm{La} / \mathrm{Yb})_{\mathrm{N}}=8.3$ all suggest a con- 
tinental arc setting for the GG shale (Table 6).

Neo-Tethys opened during Late Permian time between the present Afro-Arabian and Iranian plates with NW-SE-trending [47]. The Neo-Tethys ocean had two axises of spreading [48]; the first between the present Zagros thrust zone and Sanandaj-Sirjan segment (Neo-Tethys I), and the second between the Sanandaj-Sirjan and Central Iran (Neo-Tethys II). Spreading in Neo-Tethys I ceased in the Middle Triasic whereas spreading in Neo-Tethys II halted in Early Cretaceous. The Neo-Tethys I subduction and closure is thought to have taken place in the Campanian and Upper Cretaceous-Lower Paleocene respectively. The subduction of Neo-Tethys II beneath Central Iran plate during the Upper Cretaceous to Paleogene and following collision of Iranian and Arabian plate (continent-continent collision) during the Neogene was responsible for developing three ribbon structural zones in Iran (Figure 1) e.g. [49]-[51]. These SE trending structural zones are including the folded-thrust Zagros belt, Sanandaj-Sirjan metamorphic zone, and Urumieh-Dokhtar magmatic arc (UDMA). The NW-trending Alborz-Azarbaijan magmatic belt (AAMB) that stretches from the Alborz Mountains to Azarbaijan Province is separated from the UDMA to the south by the Tabriz Fault. Magmatic activity in UDMA and AAMB initiated in the Late Cretaceous and continued during Eocene until Quaternary period. Identical lithologic sequences of the same age in the UDMA and the AAMB propose that the two originally formed a single continental margin magmatic arc that was subsequently rifted apart [52]. The boundary (Tabriz fault) is a sharp, distinct, deep-seated, high-angle fault zone. The juxtaposition of the AAMB and the UDMA is considered to be a result of the early Cenozoic arc-continent collisional processes due to the northeastward subduction of a narrow, elongated back-arc basin beneath the western-southwestern part of the Alborz-Azarbaijan continental block, which existed as a small segment of the Neo-Tethyan oceanic crust between the UDMA and the Alborz-Azarbaijan microcontinent [50] [51]. Azizi and Jahangiri [53] proposed that the AAMB is related to the Khoy-Zanjan oceanic subduction beneath the Alborz-Azarbaijan plate and not to the Neo-Tethyan subduction beneath the Iranian plate. The studied sedimentary basin is located in the AAMB. The present geochemical data show a continental arc setting for the studied sediments that is consistent with the above findings about the AAMB. Overall, the AAMB is thought to be an immature continent arc in Upper Cretaceous-Paleocene and has formed by the Neo-Tethys II or back-arc subduction.

\section{Conclusion}

Geological studies show that the Neo-Tethys II subduction under the Central and NW Iran has been active during the Upper Cretaceous to Late Miocene [54]. Therefore the volcanic-sedimentary succession, including thick layers of acidic to intermediate volcanic rocks associated with marl, limestone, sandstone, molasse and basic volcanic rock, could be formed during Upper Cretaceous to Paleocene. Based on detailed observation of facies distribution in the NW Iran including Ahar, Kaleybar, and Heris area (Figure 11) and the geochemical characteristics of the GG shale, we infer that the 


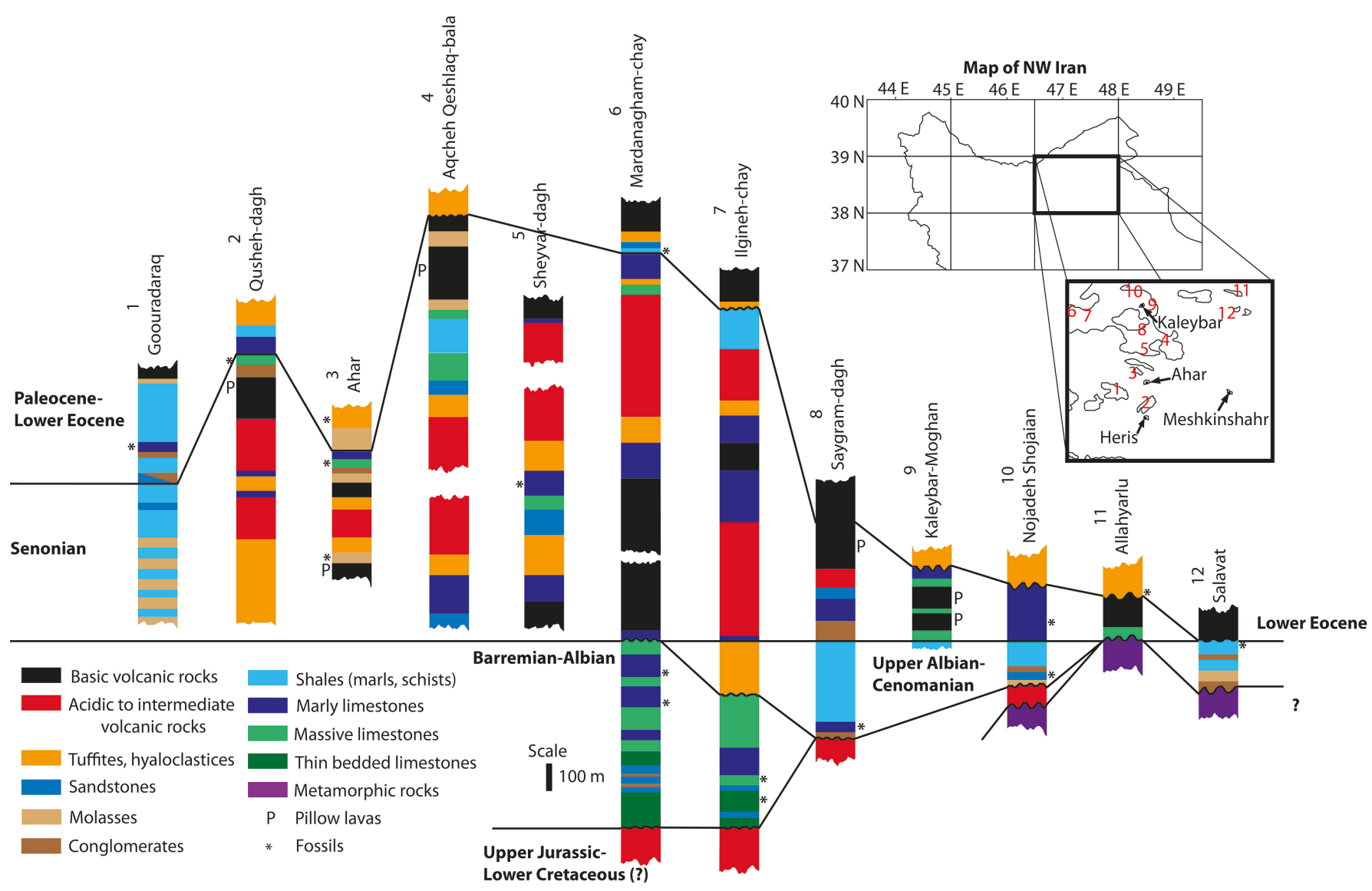

Figure 11. Comparison of the stratigraphic sections of Cretaceous and Paleocene-Lower Eocene in NW Iran (adapted from [20]). Index map shows location of the sections. The first section indicates stratigraphy of the studied area.

studied sediments were supplied from the Upper Cretaceous volcanic-sedimentary succession which occurred in the vicinity of studied area and formed in/around immature continental magmatic arc of Neo-Tethys II.

\section{Acknowledgements}

This work was financially supported by the Research Branch of the Payame Noor University (Iran), for which we are grateful. We also acknowledge contributions of the reviewers in improving the manuscript by providing valuable suggestions.

\section{References}

[1] Bhatia, M.R. and Crook, K.A.W. (1986) Trace Element Characteristics of Greywackes and Tectonic Setting Discrimination of Sedimentary Basins. Contributions to Mineralogy and Petrology, 92, 181-193. http://dx.doi.org/10.1007/BF00375292

[2] Roser, B.P. and Korsch, R.J. (1986) Determination of Tectonic Settings of Sandstone-Mudstone Suits Using $\mathrm{SiO}_{2}$ Content and $\mathrm{K}_{2} \mathrm{O} / \mathrm{Na}_{2} \mathrm{O}$ Ratio. Journal of Geology, 94, 635-650. http://dx.doi.org/10.1086/629071

[3] Roser, B.P. and Korsch, R.J. (1988) Provenance Signatures of Sandstonemudstone Suites Determined Using Discriminant Function Analysis of Major-Element Data. Chemical Ge- 
ology, 67, 119-139. http://dx.doi.org/10.1016/0009-2541(88)90010-1

[4] Taylor, S.R. and McLennan, S.M. (1991) Sedimentary Rocks and Crustal Evolution: Tectonic Setting and Secular Trends. Journal of Geology, 99, 1-21.

http://dx.doi.org/10.1086/629470

[5] McLennan, S.M., Hemming, S., McDaniel, D.K. and Hanson, G.N. (1993) Geochemical Approaches to Sedimentation, Provenance, and Tectonics. In: Johnson, M.J. and Basu, A., Eds., Processes Controlling the Composition of Clastic Sediments, Geological Society of America, Colorado, 21-40. http://dx.doi.org/10.1130/spe284-p21

[6] Fedo, C.M., Nesbitt, H.W. and Young, G.M. (1995) Unraveling the Effects of K-Metasomatism in Sedimentary Rocks and Paleosols, with Implications for Paleoweathering Conditions and Provenance. Geology, 23, 921-924. http://dx.doi.org/10.1130/0091-7613(1995)023<0921:UTEOPM>2.3.CO;2

[7] Nesbitt, H.W., Young, G.M., Mclennan, S.M. and Keays, R.R. (1996) Effects of Chemical Weathering and Sorting on the Petrogenesis of Siliciclastic Sediments, with Implications for Provenance Studies. Journal of Geology, 104, 525-542. http://dx.doi.org/10.1086/629850

[8] Cullers, R.L. (2000) The Geochemistry of Shales, Siltstones and Sandstones of Pennsylvanian-Permian Age, Colorado, USA: Implications for Provenance and Metamorphic Studies. Lithos, 51, 181-203. http://dx.doi.org/10.1016/S0024-4937(99)00063-8

[9] Paikaray, S., Banerjee, S. and Mukherji, S. (2008) Geochemistry of Shales from the Paleoproterozoic to Neoproterozoic Vindhyan Supergroup. Implications on Provenance, Tectonics and Paleoweathering. Journal of Asian Earth Sciences, 32, 34-48. http://dx.doi.org/10.1016/j.jseaes.2007.10.002

[10] Gosh, S. and Sarkar, S. (2010) Geochemistry of Permo-Triassic Mudstone of the Satpura Gondwana Basin, Central India: Clues for Provenance. Chemical Geology, 277, 78-100. http://dx.doi.org/10.1016/j.chemgeo.2010.07.012

[11] Cao, J., Wu, M., Chen, Y., Hu, K., Bian, L., Wang, L. and Zhang, Y. (2012) Trace and Rare Earth Element Geochemistry of Jurassic Mudstones in the Northern Qaidam Basin, Northwest China. Chemie der Erde-Geochemistry, 72, 245-252. http://dx.doi.org/10.1016/j.chemer.2011.12.002

[12] Setti, M., Lopez-Galindo, A., Padoan, M. and Garzanti, E. (2014) Clay Mineralogy in Southern Africa River Muds. Clay Minerals, 49, 717-733. http://dx.doi.org/10.1180/claymin.2014.049.5.08

[13] Maslov A.V., Mizens, G.A., Podkovyrov, V.N., Nozhkin, A.D., Sokur, T.M., Malinovskii, A.I., Sorokin, A.A., Smirnova, Yu, N., Gareev, E.Z., Dmitrieva, N.V., Krupenin, M.T. and Letnikova, E.F. (2015) Synorogenic Clay Rocks Specifics of Bulk Composition and Paleotectonics. Geochemistry International, 53, 510-533. http://dx.doi.org/10.1134/S0016702915060075

[14] Ehlers, E.G. and Blatt, H. (1982) Petrology: Igneous, Sedimentary, and Metamorphic. W.H. Freeman and Company, New York.

[15] Keith, M.L. and Degens, E.T. (1959) Geochemical Indicators of Marine and Freshwater Sediments. In: Abelson, P.H., Ed., Researches in Geochemistry, John Wiley and Sons, New York, 511.

[16] Blatt, H. (1985) Provenance Studies and Mudrocks. Journal of Sedimentary Petrology, 55, 69-75.

[17] Cox, R., Lowe, D.R. and Cullers, R.L. (1995) The Influence of Sediment Recycling and Basement Composition of Evolution of Mudrock Chemistry in the Southwestern United States. Geochimica et Cosmochimica Acta, 59, 2919-2940. 
http://dx.doi.org/10.1016/0016-7037(95)00185-9

[18] Graver, J.I. and Scott, T.J. (1995) Trace Elements in Shale as Indicators of Crustal Province and Terrain Accretion in the Southern Canadian Cordillera. Geological Society of America Bulletin, 107, 440-453. http://dx.doi.org/10.1130/0016-7606(1995)107<0440:TEISAI>2.3.CO;2

[19] Cullers, R.L. (1988) Mineralogical and Chemical Changes of Soil and Stream Sediment Formed by Intense Weathering of the Danberg Granite, Georgia, USA. Lithos, 21, 301-314. http://dx.doi.org/10.1016/0024-4937(88)90035-7

[20] Babakhani, A.R., Lesquyer, J.L. and Riou, R. (1990) Geological Map of Ahar Quadrangle. Geological Survey of Iran, Tehran. (Scale 1/250,000)

[21] Alavi, M. (1991) Tectonic Map of the Middle East, 1/5000000. Geological Survey of Iran, Tehran.

[22] Aghanabati, A. (2006) Geology of Iran. Geological Survey of Iran, Tehran, 586. (In Persian)

[23] Faridi, M. and Hagh Farshi, E. (2006) Geological Map of Khoja. Geological survey of Iran, Tehran, Iran. (Scale 1/100,000)

[24] Taylor, S.R. and McLennan, S.M. (1985) The Continental Crust: Its Composition and Evolution: An Examination of the Geochemical Record Preserved in Sedimentary Rocks. Blackwell Science, Oxford, 312.

[25] Boynton, W.V. (1984) Geochemistry of Rare Earth Elements: Meteorite Studies. In: Henderson, P., Ed., Rare Earth Element Geochemistry, Elsevier, New York, 63-114. http://dx.doi.org/10.1016/B978-0-444-42148-7.50008-3

[26] Moore, D.M. and Reynolds, R.C. (1997) X-Ray Diffraction and the Identification and Analysis of Clay Minerals. Oxford University Press, Oxford, 378.

[27] Herron, M.M. (1988) Geochemical Classification of Terrigenous Sands and Shales from Core or Log Data. Journal of Sedimentary Research, 58, 820-829.

[28] Condie, K.C. (1993) Chemical Composition and Evolution of the Upper Continental Crust: Contrasting Results from Surface Samples and Shales. Chemical Geology, 104, 1-37. http://dx.doi.org/10.1016/0009-2541(93)90140-E

[29] Gromet, L.P., Dymek, R.F., Haskin, L.A. and Korotev, R.L. (1984) The "North American Shale Composite": Its Compilation, Major and Trace Element Characteristics. Geochimica et Cosmochimica Acta, 48, 2469-2482. http://dx.doi.org/10.1016/0016-7037(84)90298-9

[30] Stumm, W. and Morgan, J.J. (1981) Aquatic Chemistry: An Prologue Emphasizing Chemical Equilibra in Natural Waters. John Wiley and Sons, New York, 780.

[31] Sugitani, K., Horiuchi, Y. and Adachi, M. (1996) Anomalously Low $\mathrm{Al}_{2} \mathrm{O}_{3} / \mathrm{TiO}_{2}$ Values for Archean Cherts from the Pilbara Block, Western Australia-Possible Evidence for Extensive Chemical Weathering on the Early Earth. Precambrian Research, 80, 49-76. http://dx.doi.org/10.1016/S0301-9268(96)00005-8

[32] Hayashi, K., Fujisawa. H., Holland, H.D. and Ohmoto, H. (1997) Geochemistry of 1.9 Ga sedimentary Rocks from Northeastern Labrador, Canada. Geochimica et Cosmochimica Acta, 61, 4115-4137. http://dx.doi.org/10.1016/S0016-7037(97)00214-7

[33] Bhatia, M.R. (1983) Plate Tectonics and Geochemical Composition of Sandstones. Journal of Geology, 91, 611-627. http://dx.doi.org/10.1086/628815

[34] Nesbitt, H.W. and Young, G.M. (1984) Prediction of Some Weathering Trends of Plutonic and Volcanic Rocks Based on Thermodynamic and Kinetic Considerations. Geochimica et Cosmochimica Acta, 48, 1523-1534. http://dx.doi.org/10.1016/0016-7037(84)90408-3

[35] Nesbitt, H.W. and Young, G.M. (1989) Formation and Diagenesis of Weathering Profiles. 
Journal of Geology, 97, 129-147. http://dx.doi.org/10.1086/629290

[36] Bhatia, M.R. (1985) Rare-Earth Element Geochemistry of Australian Paleozoic Graywackes and Mudrocks: Provenance and Tectonic Control. Sedimentary Geology, 45, 97-113. http://dx.doi.org/10.1016/0037-0738(85)90025-9

[37] Nesbitt, H.W. and Young, G.M. (1982) Early Proterozoic Climates and Plate Motions Inferred from Major Element Chemistry of Lutites. Nature, 299, 715-717. http://dx.doi.org/10.1038/299715a0

[38] McLennan, S.M. (1993) Weathering and Global Denudation. Journal of Geology, 101, 295303. http://dx.doi.org/10.1086/648222

[39] Harnois, L. (1988) The CIW Index: A New Chemical Index of Weathering. Sedimentary Geology, 55, 319-322. http://dx.doi.org/10.1016/0037-0738(88)90137-6

[40] Nesbitt, H.W., Fedo, C.M. and Young, G.M. (1997) Quartz and Feldspar Stability, Steady and Non-Steady-State Weathering and Pedogenesis of Siliciclastics Sands and Muds. Journal of Geology, 105, 173-191. http://dx.doi.org/10.1086/515908

[41] Young, G.M. and Nesbitt, H.W. (1999) Paleoclimatology and Provenance of the Glaciogenic Gowganda Formation (Paleoproterozoic), Ontario, Canada: A Chemostratigraphic Approach. Geological Society of America Bulletin, 111, 264-274. http://dx.doi.org/10.1130/0016-7606(1999)111<0264:PAPOTG>2.3.CO;2

[42] Nesbitt, H.W. (2003) Petrogenesis of Siliciclastic Sediments and Sedimentary Rocks. In: Lenz, D.R., Ed., Geochemistry of Sediments and Sedimentary Rocks, Geotext 4, Geological Association of Canada, Newfoundland, 39-51.

[43] Hessler, A.M. and Lowe, D.M. (2006) Weathering and Sediment Generation in the Archean: An Integrated Study of the Evolution of Siliciclastic Sedimentary Rocks of the $3.2 \mathrm{Ga}$ Moodies Group, Barberton Greenstone Belt, South Africa. Precambrian Research, 151, 185 210. http://dx.doi.org/10.1016/j.precamres.2006.08.008

[44] Cullers, R.L. and Podkovyrov, V.M. (2002) The Source and Origin of Terrigenous Sedimentary Rocks in the Mesoproterozoic Ui Group, Southeastern Russia. Precambrian Research, 117, 157-183. http://dx.doi.org/10.1016/S0301-9268(02)00079-7

[45] Pettijohn, F.J., Potter, P.E. and Siever, R. (1987) Sand and Sandstone. Springer, Berlin, 553. http://dx.doi.org/10.1007/978-1-4612-1066-5

[46] Van de Kamp, P.C. and Leake, B.E. (1985) Petrography and Geochemistry of Feldspathic and Mafic Sediments of the Northeastern Pacific Margin. Transactions of the Royal Society of Edinburgh Earth Sciences, 76, 411-449. http://dx.doi.org/10.1017/S0263593300010646

[47] Berberian, M. (1983) Structural Evolution of the Iranian Plateau; Contribution to the Seismotectonics of Iran, Part IV: Continental Deformation in the Iranian Plateau. Geological Survey of Iran, Report 52, 19-68.

[48] Glennie, K.W. (2001) Neo-Tethys 1 and Neo-Tethys 2: Successive Permian to Cenozoic Oceans That Flanked Northeast Arabia. International Conference on the Geology of Oman, Sultan Qaboos University, Muscat, 2001, Abstract.

[49] Berberian, F. and Berberian, M. (1981) Tectono-Plutonic Episodes in Iran. In: Gupta, H.K. and Delany, F.M., Eds., Zagros-Hindu Kush-Himalaya Geodynamic Evolution, Geodynamics Series, Vol. 3, American Geophysical Union, Washington DC, 5-32.

[50] Alavi, M. (1994) Tectonics of the Zagros Orogenic Belt of Iran: New Data and Interpretations. Tectonophysics, 229, 211-238. http://dx.doi.org/10.1016/0040-1951(94)90030-2

[51] Alavi, M. (1996) Tectonostratigraphic Synthesis and Structural Style of the Alborz Mountain System in Iran. Journal of Geodynamics, 21, 1-33. 
http://dx.doi.org/10.1016/0264-3707(95)00009-7

[52] Hassanzadeh, J., Ghazi, A.M., Axen, G. and Guest, B. (2002) Oligomiocene Mafic-Alkaline Magmatism North and Northwest of Iran: Evidence for the Separation of the Alborz from the Urumieh-Dokhtar Magmatic Arc. Geological Society of America Abstracts with Programs 34, 331.

[53] Azizi, H. and Jahangiri, A. (2008) Cretaceous Subduction-Related Volcanism in the Northern Sanandaj-Sirjan Zone, Iran. Journal of Geodynamics, 45, 178-190.

http://dx.doi.org/10.1016/j.jog.2007.11.001

[54] Berberian, M. (1983) The Southern Caspian: A Compressional Depression Floored by a Trapped, Modified Oceanic Crust. Canadian Journal of Earth Sciences, 20, 163-183.

http://dx.doi.org/10.1139/e83-015

Submit or recommend next manuscript to SCIRP and we will provide best service for you:

Accepting pre-submission inquiries through Email, Facebook, LinkedIn, Twitter, etc.

A wide selection of journals (inclusive of 9 subjects, more than 200 journals)

Providing 24-hour high-quality service

User-friendly online submission system

Fair and swift peer-review system

Efficient typesetting and proofreading procedure

Display of the result of downloads and visits, as well as the number of cited articles

Maximum dissemination of your research work

Submit your manuscript at: http://papersubmission.scirp.org/ 